\title{
Erratum bij: 'Effectiviteit van full-contactzolen voor drukverdeling bij diabetespatiënten met neuropathie bij specifieke activiteiten'
}

\author{
Maureen Limpens
}

Published online: 28 February 2019

(C) Bohn Stafleu van Loghum is een imprint van Springer Media B.V., onderdeel van Springer Nature 2019

\section{Erratum bij:}

Podosophia (2018) 26:38-41,

https://doi.org/10.1007/s12481-018-0179-8

In het artikel 'Effectiviteit van full-contactzolen voor drukverdeling bij diabetespatiënten met neuropathie bij specifieke activiteiten' (Podosophia, maart 2018, Volume 26, issue 1, pp. 38-41) is onvoldoende duidelijk dat het een samenvatting betreft van het artikel 'Effectiveness of total contact orthosis for plantar pressure redistribution in neuropathic diabetic patients during different walking activities', van M. Nouman, W. Leelasamran en S. Chatpun, dat is gepubliceerd in Foot Ankle International 2017;38(8):901-8. (https://doi.org/10.1177/1071100717704427).
De redactie betreurt deze onduidelijkheid en biedt hiervoor haar excuses aan.

Maureen Limpens, hoofdredacteur

De online versie van de originele bijdrage vindt $\mathrm{u}$ onder https://doi.org/10.1007/s12481-018-0179-8.

M. Limpens $(\varangle)$

Bohn Stafleu van Loghum, Houten, Nederland

m.limpens@bsl.nl 